\title{
Political apprenticeship and women leadership in a patriarchal society: Nasim Wali Khan's political struggle through acquired skills
}

\author{
Hassina Bashir* | Muhammad Ayub Jan \\ Department of Political Science, University of Peshawar, Peshawar, Pakistan. \\ *Correspondence Emails: hassinabashir10@uop.edu.pk | hassinabashir10@yahoo.com
}

\begin{abstract}
:
This paper addresses the critical aspects of women's political leadership in Pashtun society. The primary questions under investigation are; whether Nasim Wali Khan acquired political leadership skills and if she did, how she utilized these skills to accomplish her political objectives? We intend to see how familial political apprenticeship as well as career progression, enabled Nasim Wali to attain and retain leadership positions successfully? We do so mostly with the help of analyzing primary data collected through in-depth interviews of Nasim Wali Khan, her family members, political workers, journalists, and academicians to comprehend to support our argument. This study highlights the qualities bestowed with and acquired by Nasim Wali Khan to attain a leadership position within a political party. The study argues that by developing her political skills, such as political acumen, eloquence, political astuteness, efficient decision making, confidence, and social astuteness, etc., Nasim Wali auspiciously engraved a political constituency in an otherwise patriarchal Pukhtun population. In such a way the paper explains the critical odyssey of Nasim Wali Khan in the uncertain sphere of politics.
\end{abstract}

\section{Article History}

Received:

January 20, 2021

Last Revised:

April 28, 2021

Accepted:

April 30, 2021

Published:

June 19, 2021

Keywords: political affiliation, political familial affiliation, leadership skills, women leadership, women political leadership, patriarchy, patriarchal society, Pakhtuns leader.

\section{How to Cite:}

Bashir, H. \& Jan, M. A. (2021). Political apprenticeship and women leadership in a patriarchal society: Nasim Wali Khan's political strive through acquired skills. Liberal Arts and Social Sciences International Journal (LASSIJ), 5(1), 320-337. https://doi.org/10.47264/idea.lassij/5.1.21

\section{Publisher's Note:}

IDEA PUBLISHERS (IDEA Journals Group) stands neutral with regard to the jurisdictional claims in the published maps and the institutional affiliations.

Copyright: () 2021 The Author(s), published by IDEA PUBLISHERS (IDEA Journals Group). This is an Open Access article published under the Creative Commons Attribution-NonCommercial 4.0 International License (http://creativecommons.org/licenses/by-nc/4.0/) 


\section{Introduction}

The existing literature on women's political leadership often considers political familial affiliations as the basic reason behind the accomplishments of the prominent women political leaders in Asia (see, Jalalzai \& Krook, 2010, p.08; Fleschenberg, 2008, p. 24; Derichs \& Thompson, 2013). Such claims lack a more nuanced understanding of the role of leadership skills acquired by women in the course of their political careers. Women throughout the world face problems in obtaining leadership roles, therefore, they always strive hard to create a remarkable impact in various fields (Neely, 2012). Women are passionate and interested to attain leading positions in different areas including politics. More specifically, women political leaders are capable to build their constituency by interacting with and influencing millions of people for political support. This requires substantial political skills. A political apprenticeship enables women leaders to acquire these crucial leadership skills and become aspiring role models for generations.

Political apprenticeship assists political participants to gain confidence and efficiently raise their voices on various problems (Stock, 2012, p. 02). Wenger (1998, p. 11) states that apprenticeship is the 'learning process'. Lave and Wenger (1991, p. 29) explain that apprenticeship creates a 'community of practice' where tasks and values are shared. Likewise, particular skills, knowledge, and social practices of the community are also conveyed from one generation to another. The role of the family in imparting political apprenticeship is also significant. Families having political backgrounds assist and prepare their eligible members to hold political offices. These politically active families confer free apprenticeship and political socialization to their young generations (Jalalzai \& Rincker, 2018, p. 03). Individuals after acquiring these skills and knowledge embark upon political careers and attain leading positions in politics. After acquiring leadership positions, individuals persistently struggle with devotion to public service and finally succeed in getting public support.

This paper discusses the above debates through the case study of a women political leader of Pakistan i.e., Begum Nasim Wali Khan. Nasim Wali Khan was the first- ever female elected member of the parliament and the leader of a political party. Nasim Wali Khan was born in 1936 at Hoti village in District Mardan of Khyber Pukhtunkhwa province of Pakistan. Ethnically she belongs to Pakhtun identity which constitutes the second most numerous ethnic groups of Pakistan. Her father, Amir Mohammad Khan, was a close companion of Ghaffar Khan and a prominent activist of the Khudai Khidmatgar movement. In 1954, Nasim Wali Khan tied a knot with Abdul Wali Khan, a renowned political figure and the son of influential Nationalist leader Abdul Ghaffar Khan. Nasim Wali Khan's family was already involved in the politics of the region even before her marriage. Nasim Wali Khan acquired and retained party leadership, partly, through the skills she acquired from her political family and partly, through her own practical experience in politics. Thus, her brought up in a political environment and later her marriage into a political family enabled her to learn the crucial skills of political leadership. However, such political apprenticeship was not exclusively responsible for the rise and survival of Nasim Wali Khan as a leader. Throughout her political career, Nasim Wali groomed her leadership skills and carved out a leadership space for herself, which makes her an interesting case study to explore.

\subsection{Research objectives and questions}

This paper aims to explore whether Nasim Wali Khan acquired leadership skills and if she did, 
how she utilized these skills to accomplish her political objectives? The explanation is crucial to understand the career of Nasim Wali Khan as a political leader. However, in this paper, we also argue that skills are not the innate features possessed by leaders. They are learned either through family apprenticeship or through career progression. Leaders improvise along with the progression in their political career and they do so through their struggle. We intend to see how familial political apprenticeship as well as career progression, enabled Nasim Wali to attain and retain leadership positions successfully? These inquiries will further improve our understanding of the often-ignored personal struggle of women political leaders in Asian societies. Therefore, it is significant to investigate; how political leaders groom themselves through political apprenticeship but also to look into the career paths of the political leaders? But a supplementary question is also crucial to such inquiries i.e., which particular skills are required for political leadership and why?

\subsection{Significance of the study}

The rise of Nasim Wali Khan as a political figure is an interesting case of women's struggle for empowerment and political leadership. Limited examples and fewer research studies are exploring such phenomenon. It is interesting to note that Nasim Wali Khan observed most of the traditional cultural norms, yet maneuvered other norms to deal with the exigency of her time. She accepted the responsibilities to lead her people and sacrifice her family life. The leadership of females is not culturally welcoming in traditional societies and therefore, not widely accepted. Not only did she continue to express her will to lead despite all the odds, but she continued to inspire as well. This paper opens new avenues of research in the arena of female political leadership with special reference to their struggles in confronting challenges in traditional societies, such as the Pukhtun. Moreover, this study helps us develop our understanding of females as active agents in politics and not mere passive individuals patronized by male members of their societies.

The significance of this study is also visible from the novel approach of this study. Earlier literature (Fleschenberg, 2008; Derich \& Thompson, 2013) emphasized the dynastic political inheritance of leadership by women. Previous literature assumed that politically targeted males provided opportunities for women of these affected families to rise as political leaders. Such studies do not systematically examine the skills of women political leaders. This paper evaluates the subject by relying on individual experiences and extensive skills that enabled and empowered women of the patriarchal societies to become public leaders. Therefore, the paper argues that besides familial ties and favourable situations, political skills are crucial variables for the attaining and retaining of top political leadership positions.

\section{Theoretical framework}

The skills theory of leadership provides the most appropriate insights into the problem of women's political leadership in Asia. More specifically, through this theoretical debate, we are looking into leadership skills that facilitate or hinder women political leaders to acquire and sustain leadership positions. The skills theory emphasizes that those political figures having the ability and appropriate skills to manoeuvre the situation, emerge as leaders. Women are often allotted top leadership position in challenging situations (Haslam, 2004). This is because women are considered to own qualities (like empathy, collaboration and efficient communication etc) suitable to handle crisis situations. 
Some scholars argue differently and assert that females of the elite families take the lead in crisis situation (Skard, 2015, p. 154). Women become the 'beneficiaries' of their strong political families. Their brought up in the political environment prepare them for leadership positions. Such 'political apprenticeship' (Cornwall \& Goetz, 2005) is used as a steppingstone by women leaders to enter leadership position, but I argue that after acquiring leadership positions, they require more extensive skills and grooming which are achieved by women leaders through their experience in active politics

Though crises may help women leaders to rise they may also put women leaders to the test. Women find an opportunity of leadership in crisis situations but once they avail that opportunity, they find it quite challenging. It requires them to have more extensive skills to survive the challenge. This then requires new skills that are more relevant to the changing situation. Political acumen, eloquence, good decision making, social astuteness, and confidence are the acquired skills that they further polish through their experiences. These acquired skills facilitate women leaders to sustain their leadership positions for long.

In this paper, we will investigate some particular skills of Nasim Wali Khan along with other possible strategic reasons for choosing the leader of the National Awami Party (NAP). This is particularly important because the literature identify skills such as social astuteness (Ferris $e t$ al., 2005), communicative action (Habermas, 1984, p. 86), confidence and determination (Bass, 1999, p. 11), interpersonal and decision-making (Lussier \& Achua, 2013, pp. 10-11), good oratory and charisma (Bennister, 2012, p. xiii) are relevant in crisis. However, after attaining a leadership position the challenges are met through more extensive leadership skills demonstrated by leaders.

The scholars argue that those political leaders who possess skills such as ambitiousness, political acumen, ability to use the available opportunities, superior oratory (Bennister, 2012, p. xiii), interpersonal or communication (Katz et al., 1974), effective decision making (Lussier \& Achua, 2013, pp. 10-11), confidence and social astuteness (Ammeter et al., 2002, pp. 764765), etc are considered crucial for retaining leadership position. Such political leaders have greater chances of success. They can utilize these skills to exploit political opportunities and achieve their goals.

Moreover, it is important to look into how these skills are required by woman political leader Nasim Wali Khan. She gained leadership skills partly by family training (political apprenticeship) and partly by the gradual process of accumulating political experience. This paper would highlight how Nasim Wali Khan acquired and groomed the appropriate skills and how she used them to retain political leadership. Additionally, how she inspired her followers in testing times of the 1970s and secured their support to achieve the purpose.

\section{Research methodology}

A qualitative research design is used in this study. Both primary and secondary sources of data collection were used to find answers to the questions raised in this study. Primarily, semistructured interviews were conducted with respondents including journalists, politicians, academicians, and lawyers. Additionally, multiple rounds of interviews were conducted with Nasim Wali Khan, her close party associates, and her family members to elicit details about the life, character, and struggle of Nasim Wali Khan. Secondary data from books, articles, and journals were collected to build a historical context of the study and also to improve our 
understanding regarding the historical perspective of Nasim Wali Khan's leadership struggle. Various reports and documents regarding women's political leadership in Pakhtun society were also used to add to the ethnic context of Nasim Wali Khan's leadership struggle.

\section{Nasim Wali Khan as political leader: A discussion}

It is pertinent to give a detailed account of the selected leadership skills of Nasim Wali Khan which enabled her to attain and the retain leadership positions despite all the political and societal challenges she confronted.

\subsection{Political acumen}

Political acumen is a crucial skill required by political leaders to attain and then retain top political leadership positions. Political leaders with such skills get a better understanding of the problems faced by people and try to find effective and appropriate solutions. Consequently, these leaders win valuable public support and enable them to carve out political space for themselves. When such space is carved out, it becomes more important to sustain that space which again requires political acumen.

Moreover, it might be easier for women of prominent political families to attain leading positions in comparison with general women, however, such an opportunity brings its unique challenges. For example, these women leaders will have to work in the male- dominated political space, where their demeanour would be under the strict scrutiny of men for their social propriety. Therefore, women, despite their familial advantage, are under consistent pressure to prove themselves in such challenging situations.

Our interview data advocates that Nasim Wali Khan demonstrated significant political acumen in difficult times. Mindful of the sufferings of her family, Nasim Wali joined the political field to proceed with the legacy of her family. She had a good understanding of her situation and the political situation of the time. She was supposed to create political space for herself in these demanding situations (Rahimullah Yousafzai, personal interview, 2017; Fayaz Khan, interview, 2017). Storey et al., (2017, p. 202) argue that politically astute leaders can comprehend diverse situations and can ably create a favourable and supportive political environment for themselves, even in crisis situations. Political acumen empowers political figures to earn the confidence and trust of their followers (Ammeter et al., 2002, pp. 764-765) and can attain an authorizing position as well (Storey et al., 2017, p. 202). Likewise, Nasim Wali Khan used her political acumen and dealt with political matters accordingly. In the process she was able to win public support in her favour. A critical question arises here as, how Nasim Wali Khan amassed the political acumen being a devoted house wife with no formal political training?

As mentioned earlier, prominent political families impart political acumen among capable family members. Likewise, Nasim Wali Khan being a member of the renowned political family inherited political acumen. Political discussions at home and contacts with eminent political figures visiting her home would assist her to attain political awareness. Such a political atmosphere imparted political cognizance which persuaded her towards politics. Nasim Wali Khan in an interview with the author confessed that her birth in a prominent political family of Mardan (KP), where she saw her father's commitments with Khudai Khidmatgar movement trained her. Afterward, her marriage with Abdul Wali Khan (successor of Ghaffar Khan), 
provided a more valuable opportunity for her political grooming. Nasim Wali saw more arduous political activity in her new home because the home of Wali Khan was a centre of political activities since the British Raj. Being a member of such a renowned family, her acquaintance and acumen about politics further groomed and matured (Wali, interview, 2016).

Literature on women political leaders (Jalalzai \& Krook, 2010, p. 08; Fleschenberg, 2008: p. 24; Derichs \& Thompson, 2013) and our interview respondents (Shagufta Malik, personal interview, 2017; Rahimullah Yousafzai, personal interview, 2017) consider political family background as essential aspect in the prosperous political career of women political leaders. However, we go beyond the above argument suggested by the literature and argue that familial ties do inculcate political acumen among its members, but the proper use of political acumen is also one of the unique skills needed by any political leader for their successful political career. The question is, had Nasim Wali Khan not acquired political acumen from her family, would she have been able to join and stayed for long in her political life?

We argue that though Nasim Wali Khan amasses political acumen through renowned political family, nevertheless, it was her proficiency to avail and manoeuvre the instilled political acumen appropriately. Her sound political acumen encouraged her to confront numerous barriers competently and act accordingly. The way she disproved all the myths uttered by her opponents and strived equally like her male colleagues for the accomplishment of tasks shows that besides political acumen, the skills to manoeuvre and exploit a situation also play role in the political successes of a leader. Jalalzai and Rincker (2018, p. 54) posit that politically astute person from the political family can exploit the condition in their favour, earn confidence and attention from the voters, even get great media coverage. Their prior social networks and organizations assist them to gain votes as well.

Munawar Sultana asserted in her interview that "if political leaders lack remarkable skills, no matter how much wealth they have, which prominent family they belong to and which significant posts they occupy, they would not be able to remain in power for long" (Munawar Sultana, personal interview, 2017). Our evaluation is that Nasim Wali Khan became a party leader by succeeding her confined husband which is a milestone not just because of crisis situations that enabled her to attain such a position but also because of her political acumen. Her political acumen was exhibited from her struggles which were not limited to Khyber Pukhtunkhwa (the then NWFP) but were spread throughout the country. She discussed the matters maturely in the mass gatherings. She communicated her problems in front of the public in an inspiring way but showed her unanimity with them in their sufferings most explicitly during Z. A. Bhutto's repressive rule. Through her sound strategies, she was able to create a place for herself in the male-dominated political sphere.

In her speech on $7^{\text {th }}$ December 1975 in Lahore district bar association, Nasim Wali stated that, "we are facing repression in our own country. The government is suppressing the opposition parties by all means to create a dictatorial rule of one man. When I saw nobody in my house to confront the atrocities of the government, then I considered it my responsibility to come forward. I have left the four walls of my house and raised my voice for the rights of my people. Whatever is happening in Pakistan is all before you. A single person has pushed back the whole country just for the lust of his ambitions. We expected a better future for our nation from this person. But he (Z. A. Bhutto) has achieved such heights where we don't have the potential to remove him" (Malik, 1975, pp. 11-12). 
Nasim Wali Khan in her speeches portrayed herself as a public leader, who was endeavouring for their rights and the restoration of democracy. She was struggling among those compatible individuals, who were the hope of the public to end the autocratic rule. She had discussed different important political, social, financial problems and had exposed atrocities of the government in front of the public which helped her to challenge the oppressive Z. A. Bhutto rule. Nasim Wali Khan skilfully motivated the public to gather on one platform and stood for the acquisition of their fundamental rights. Her consistent effort granted confidence to the masses who acknowledged her political endeavour. Through her political cognizance, actions, ambition, and dedication, she changed the thinking of the traditional patriarchal society. They accompanied her in her struggles against the authoritarian rule of Z. A. Bhutto.

The political acumen of Nasim Wali Khan is recognised by the fact that despite being a housewife earlier, her political apprenticeship forced the political associates to allot her the responsibility of the party leadership (Farid Tofan, personal interview, 2016). She was deeply concerned with the fate of her party and family in the deteriorating situation. Such a situation did not permit her to stay aloof from the political sphere. It was possible through her political acumen that she skilfully showed her presence in the general public without being obstructed by society. Through her political instinct, Nasim Wali Khan had metamorphosed political phenomenon in her own right.

Nasim Wali Khan's political acumen was demonstrated by the fact that not only male members of the society were her supporters, rather women of the traditional society also accompanied her. Begum Ghulam Mohammad Bilour ${ }^{1}$ acknowledged the political acumen of Nasim Wali Khan in her interview with Qalandar in 1977 in these words: "I like Nasim Wali Khan's politics. I ponder Nasim Wali Khan as my leader. I feel honoured to be present among those countless women political workers of NWFP, who are supporters of Nasim Wali Khan. The political acumen, courage and determination which she demonstrated in these testing times are very rare" (Qalandar, 1977, p. 14).

\subsection{Impressive oratory skills}

Good oratory skills facilitate political figures to attain and retain leadership positions. While analysing Nasim Wali Khan's oratory skills, it is perceived that she skilfully communicated her intentions, feelings and thoughts to the public. Her persuasive communication skills amassed the public towards her who listened to her and understood every word she uttered. Raiza Bondrey (1977, p. 13) in The Herald, a prestigious English magazine of Pakistan, appreciated her oratory skills in these words, "Public stay to listen, for she is the best speaker in the PNA line-up. Her language is Pashto, but her Urdu has a poetic fluency that defies easy translation." We argue that motivational speeches of leaders give impetus to the public specifically when such leaders struggle against corrupt and tyrant rulers. Nasim Wali Khan with persuasive communication skills achieved a successful political career in the long run. As Bondrey (1977) states, "on the public platform, perhaps what you say is not important as how you say it. And Nasim Wali Khan knows how to say it. Her style is a striking mixture of offbeat imagery, humour, emotional appeal and logic" (p. 13). Being a skilful political leader with the command of eloquence, she incited the general masses towards the accomplishments of set tasks that become easier with their assistance.

Nasim Wali Khan inherited the persuasive oratory skill from her predecessors. But the manner she demonstrated vigorous oratory skills proved to further expedite her political career. Our 
interview respondents posit that her father, Amir Mohammad Khan Hoti was a good speaker and had a great command of Lucknow Urdu. Nasim Wali Khan had a great affection towards her father and inherited the same quality from him. She possessed skills of using clear words and expression. She was a great public speaker and continues to be so. Her speeches were very influential which motivated the masses. Certainly, being Abdul Wali Khan's partner and owing to her political acumen, Nasim Wali Khan used her oratory skills to her advantage (Hameed Khan, personal interview, 2017; Fayaz Khan, personal interview, 2017).

Nasim Wali Khan's oratory skills were acknowledged by her political associates such as Sherbaz Khan Mazari, a Balochi nationalist leader ${ }^{2}$. In his autobiography, he stated that Nasim Wali delivered her first public speech in the initial public meeting of NDP at Baldia colony. He states that being female of a patriarchal society, he was impressed by her good oratory skills which she demonstrated in her first public appearance. He added that she used her natural talent by persuading the public. Mazari acknowledged that her first-ever speech made him realize that 'it was just the beginning of her lengthy political career' (Mazari, 1999, p. 389).

Similarly, one of our respondents and close associate of Nasim Wali Khan, Farid Tofan recollects the memory of a rally held in 1976 in Chowk Yadgar (a famous monument in Peshawar city). He states: "When Nasim Wali Khan came on stage accompanied by the old associates from Swabi, Mardan, and Charsadda, people were eager to listen to the first female member of Bacha Khan's family. Nasim Wali Khan in her speech stated that "I donned this black shawl as a symbol of my sorrow. I will only start using white shawl, when you people support me in my struggle to shatter the Hyderabad tribunal and release our leaders. Would you agree to put shawl on my head then I will join the political sphere and start a struggle with you? I have no alternative but to actively participate in the political field and fight against atrocities of the government". People sensed her pain and became emotional...this was one of the memorable speeches of Nasim Wali Khan which motivated the people to join her struggle against the government atrocities...our party supporters were all the old guards of KK movement, who suffered a lot during their struggle against the British, faced oppression, jails and being tortured by governments of the time. So, they felt her grief' (Farid Tofan, personal interview, 2016).

While analysing this public speech of Nasim Wali Khan, it had a deep impact on the general masses. The public was gathered under her leadership and joined her in her endeavour. She skillfully exploited her cultural code of pardah through a chadder. Her request of putting a shawl on her head refers to the honour of the women. Her emphasis on having a chadder is to use cultural norms in her favour to gain the support of followers towards realization of her task. Sultana discloses in her interview that the shopkeepers of Utmanzai (birthplace of Abdul Wali Khan) brought chadder for Nasim Wali Khan. It was a sign of their willingness to stand beside her in her political strife (Munawar Sultana, personal interview, 2017).

Derich \& Thompson argue that the portrayal of traditional Asian women political leaders as political victims boosted their chances of acceptance among the followers. Though the majority of them are politically inexperienced but their skills to generate the 'victimization sentiments' among the followers assist them to lead the political movements against the cruel, unjust and dictatorial rulers (Derich \& Thompson, 2013, pp. 16-17). Likewise, Nasim Wali Khan posits in one of her interviews with Abdul Qadir Hassan in Weekly Afrasia: "It is a requirement of the time when my Father-in-law is in jail, my husband is being declared a traitor, my elder son Asfandyar Wali is being detained on the charges of Hayat Sherpao's assassination. He was 
sentenced to 19 years. My only brother Azam is a political absconder. My father is not alive. I am now the only person to revive the political legacy of my family" (Hassan, 1977, p. 11).

Nasim Wali Khan time and again proclaimed that her presence in politics is because of the compulsion of the circumstances. Political victimization of her male family members compelled her to stand against the odds and strive for the political resurgence of her family. These statements proved to be prudent attempts to appeal to social and cultural sensitives of the masses. She worked for it by visiting every part of the country and tried to persuade the people against government charges on NAP leaders and workers. She always mentioned the historical struggle of Abdul Ghaffar Khan and her family for the rights of the people. During her speech on $2^{\text {nd }}$ November 1976, she discussed the struggle of Abdul Ghaffar Khan and argued that being a member of such a prominent family with a long history of political victimization, I am also determined to face these sufferings patiently and striving persistently until the successful accomplishment of my tasks (Sarwar, 1976, pp. 8 \& 28).

Bondrey argues that the secret of Nasim Wali Khan's triumph was partly her personality and partly the turbulent political conditions. To a public jaded with yesterday's politicians, Nasim Wali Khan came as a fresh face. She had the charisma that was otherwise absent from the political scene. "Her style, her speech, her sadar, all convey an aura of purity that was solely missing in the country's political atmosphere" (1977, p. 13). We argue that Nasim Wali Khan's tours, addressing large public gatherings, exchange of experiences with her peers and the acknowledgment by the public and party associates further improved her communication skills. Nasim Wali Khan's speeches favoured the autonomy of Pukhtuns and her struggle against the suppressive regime enhanced her credibility. She effectively raised her voice on those issues which were increasing public problems. Similarly, effective decision-making skill is also acquired by political leaders for their successful and lengthy political careers.

\subsection{Effective decision-making}

Political leaders, being the representatives of the public must possess effective decisionmaking skills. They play a crucial role to take different vital decisions for the improvement and development of the public. Nonetheless, completion of their demands is possible only through the efficient decision- making power of political leaders. Such skilful leaders gain confidence and trust in return. Supporters and followers become confident that their leaders are capable to unravel the hitches they are facing.

Zimmerman et al. (2012) argue that cognizance regarding the issue is the initial stage in the decision- making process. It is significant to state the problem. A skillful leader enumerates the tasks, collects mandatory information, and analyses different options to attain desired outcomes without ignoring uncertainties and perils. Political leaders always face hurdles which affect their decisions and judgments, nevertheless, lessons from past experiences and effort for a better future can make them able to be informed, adapt and proceed (p. 7).

Nasim Wali Khan's decision-making skills which she demonstrated by joining active politics in crisis situation, reviving the banned political party, the safe acquittal of male family members and enabling her family to survive politically are the indications of her sensible decisionmaking skills. Being an educated woman, she possesses political acumen and stands among the notable political figures. She joined politics in an era when women have a marginal presence in the political field, specifically in a patriarchal Pukhtun society. Likewise, Nasim 
Wali Khan's political acumen expedited her while taking different important decisions at the time of political suppression. She was aware of the situations and her providence enabled her to take decisions accordingly and her determination further helped her to act persistently.

Farid Tofan states that Nasim Wali Khan earned the confidence of the party associates on crucial decisions while holding the party leadership. She explained the condition to party colleagues and would state: "I take the lead given the current circumstances to reorganize the political party and release the confined party leaders. But if anyone has any objection, then select any competent person to handle the condition and to make efforts for the discharge of leaders actively. We will all welcome them. I am ready to work with them. I have no experience of active politics but want your support" (Farid Tofan, personal interview, 2016).

We assess that Nasim Wali Khan's important decision was her active participation in the political field in difficult times. This very decision boosted her political endeavour positively. Similarly, she was part of a compatible group of people who reformed a political party (NDP) at a time of political dissension which further enhanced her prestige. Being a woman, she was courageous enough to take hard decisions accordingly. Through the platform of NDP, she was able to reassemble the party associates. She accumulated mass support. She was also prosperous in her struggles of consolidating all the political parties on one platform against Bhutto's oppressive regime. Through this platform, she was able to put forward her demands before the government and was able to get them fulfilled as well. Nasim Wali Khan and Sherbaz Khan Mazari are considered to be the progressive members of the defunct party (NAP), who formed and led a new party (NDP).

Kaushik (1984, p. 78) posits that Nasim Wali Khan prepared seven points under the guidance of her party comrades. She put forward these points to the government. Nasim Wali Khan was a firm supporter of the lifting of emergency. She fought for the reinstatement of civil liberties. The political solution of Baluchistan issue; discharge of all political detainees; implementation of the 1973 constitution which was mutually sanctioned by the National Assembly; grant of admission to all educational institutions purely on merit basis, job security; lessening of unemployment and allotment of allowances during unemployment were the main issues to counter with.

Similarly, during Nasim Wali Khan and Sherbaz Khan Mazari's leadership, their political party NDP decided to join the coalition of the nine political parties named Pakistan National Alliance (PNA) against Z. A. Bhutto's government. While analysing the importance of the alliance (PNA) for NDP, we can find that on one hand, this alliance was helpful in the amalgamation of all the opposition parties on one platform. Their unification acted as a catalyst for Nasim Wali Khan's political efforts. On the other hand, we noticed that Islamic Political parties also joined the united front (PNA) against Z.A. Bhutto's suppressive rule. This was also advantageous for the prosperous political career of Nasim Wali Khan and the accomplishment of her political goals as well. Likewise, in her political endeavour, she did not face any difficulty (in the form of fatwas, the religious verdict by the religious scholars) from the Islamic Political Parties. Rather, they were her allies. Nasim Wali Khan's political acumen assisted her to play a vital role alongside various political parties (including Islamic political parties) to attain set goals.

In one of her interviews with Razia Bondrey in The Herald, Nasim Wali Khan posited: "on the night of $22^{\text {nd }}-23^{\text {rd }}$ April 1977, when I was arrested, our agitation was at its height. Bhutto sent 
an envoy with a proposal. He said that if we joined hand with the government, they would give us government in the Frontier (NWFP), there would be re-election in Baluchistan which enable us to make our government in Baluchistan as well. They would withdraw the Hyderabad tribunal case, all prisoners would be released, all cases before special tribunals and special courts would be withdrawn, but I refused" (Bondrey, 1977).

We argue that though it was a good deal as the government was willing to accept all her demands. The acceptance of the offer would have benefitted her a lot. She could have easily attained her goals without confronting the atrocities of the government. Rather she would have achieved the position of being the most desired political figure of the government. But Nasim Wali Khan decided to reject the offers given by the government. She successfully integrated the whole nation politically. The acceptance of this offer would have symbolised betraying the whole nation. Her wise decision-making skills increased her integrity among the public and political partners. They paid their regards and made her presence mandatory while taking important decisions. It is stated that pragmatic decision-making and its implementation are possible only through the skill of social astuteness. Social astuteness is used to their advantage by skilled political leaders to attain set goals (Yammarino \& Mumford, 2012, p. 33).

\subsection{Social astuteness}

We argue that political leaders amass successes mostly through awareness regarding the requirements and demands of society. Their earnest efforts further grant them a social endorsement. Moreover, the culture of the traditional societies may expedite leaders to communicate with the public in a particular manner, get to know them, and become aware of their demands and needs to earn mass support and confidence in return. It is commonly perceived that Pukhtuns have close cultural and social associations. Scholars posit that social practices shape lives of the individuals and provide them an identity as a community. Thus, societal practices manifest the importance of the community's value system and beliefs. Similarly, Pukhtuns have their societal practices. Being nurtured in Pukhtun families, children from a very early age are acquainted with their norms, customs, and culture. The persistent adherence to such societal practices enhanced the sense of belonging among the community (Vandal et al., 2013, p. 7; Lindsay, 1997).

Likewise, our evaluation is that the seniors and leading members of such communities have a significant role in the enhancement of these community associations. They are honoured by the concerned population. Their positive perspective towards the indication and solution of various issues faced by traditional communities has a great value. Under the supervision of their elders, these communities can easily overcome their problems. They act as a bridge to form and improve a situation for close social relations among them.

A Pukhtun intellectual Kaka Khail admired the devotion of a Pukhtun leader Bacha Khan, who further improved the social association and integration among Pukhtuns. At that time, mostly Pakhtuns were against women's education and had no political affiliations as well. Bacha Khan and his comrades acquainted Pukhtuns with the presence and significance of women in all fields of life. He emphasised time and again that women's participation in political and educational fields is important for the development of society. Bacha Khan convinced Pukhtuns to educate their women and empower them to contribute to the political field as well (Kakakhail, 2012). Being nurtured in such a familial environment, it was easy for Nasim Wali Khan to communicate with the public easily. But it would be interesting to know how Nasim 
Wali Khan formed a good social network? How this network contributes to her lengthy and prosperous political career?

Grima posits that Pukhtuns have characterised their events and rituals into two groups called Gham-Khadi. Gham (sorrow, griefs, sadness) as opposed to Khadi (pleasure and festivals). It is binding upon Pukhtun women to attend these events (1992, pp. 41) which bestow them prestige, political influence and authority in the society (1992, pp. 43-44). Ahmad states that females of the landlord families in a village are always at the forefront to form a good social network with different groups (other landlords, religious families, tenants and servants) of the villagers. This forms an intricate social association between landlords and villagers which they repaid at hard /crisis times (Ahmed, 2006, p. 20). Grima points towards a proverb prevalent in the Pukhtun society: one who ate the salt of someone would be indebted for ever to him/her and grant their favour in return (Grima, 1992, p. 43).

Munawar Sultana posits, that one of her maids from Charsadda informed her about Nasim Wali Khan's social life. She said that Nasim Wali Khan tried her best to attend different ceremonies arranged by the public and was very supportive and compassionate to them (Munawar Sultana, personal interview, 2017). Our interview data reveals that she is still a very social person and keen to know about the expectations and demands of the general public even at this stage of her life; when her health and age don't permit her to do so (Naeema Bibi, personal interview, 2016; Nazo Bibi, personal interview, 2016). Nasim Wali Khan formed a reputable place for her in the party through the social capital she forged through gham-khadi. Nasim Wali Khan in her interview with the author argues: "it was difficult for her to fulfill the social responsibilities along with political as well as her family responsibilities but gham-khadi enabled her to know about problems of the public and communicate her point of view to the masses" (Nasim Wali Khan, personal interview, 2017).

We argue that this social networking expedited Nasim Wali Khan and facilitated her to gain encouragement, support, and acceptability among the party followers. Nasim Wali Khan through her social astuteness gained the name-recognition Mor Bibi (mother). Our interview respondent Ihsan posits that the title Moor Bibi was granted to Nasim Wali Khan by her supporters to express their respect towards her as a mother (Zubaida Ihsan, personal interview, 2017). Motherhood is a sacred duty, having a value in religious laws and religion Islam as well. Wijekoon states that motherhood is considered to be "a good mother, manager, mediator, mate and maid". Motherhood also increases women's position in society. Female political leaders sometimes exploit the sacredness of motherhood for the purpose to attain leading positions in politics (Wijekoon, 2000, pp. 61-62). Likewise, in Pukhtun society, the mother has great regard at home as well as in the community as a whole. Ahmed (1980) argues that Pukhtuns intensely believe in the saying of Prophet Mohammad (PBUH) when He said "Moor da khpu lande Jannat de" (Heaven lies at the feet of mother).

Driedger (2013, p. 13) posits that women face hardships and challenges as compared to male members for the public office. But Hussain states that the skills of Nasim Wali Khan assisted her to overcome various obstacles in her political strife. She never acted like an ordinary oppressed woman. She behaved extraordinarily, interacted with the public socially in hujras (male guest house) as well, and ably unified them under the leadership of NDP. The public was supportive and paid their regard to a female who resisted a suppressive government. May be one of the causes of such non-resistance was that her physical presence in politics was not exceptional. There were females from Pukhtun society who contributed dynamically to the $K K$ 
movement of Bacha Khan. After the independence of Pakistan, there were names of few prominent Pukhtun women political leaders who were active both socially and politically. They have attained significant places in the politics of Pakistan. So, the presence of Nasim Wali Khan in the political arena was not surprising to the general public as well (Khadim Hussain, personal interview, 2017).

We argue that her optimistic image was engraved in the minds of the public which amassed her successes in the political sphere as well. Though being a member of the traditional society, social interaction of females is hard as compared to males of the family or society. It is easy for a male to make good social capital. However, it is very hard for female politicians to intermingle socially because of the socio-cultural taboos, patriarchal notions, and religious hindrances. Thus, in many parts of the Pukhtun society, females are still barred from using their electoral rights during elections. It is, therefore, a great accomplishment on part of Nasim Wali Khan to navigate through these obstacles successfully. Apart from all the above skills, confidence is also another vital skill required by political leaders to accomplish goals and pursue a prosperous political career.

\subsection{Exceptional confidence}

It is commonly observed that most confident leaders have the ability to take accurate decisions at the appropriate time for purposeful political outcomes. They are competent to confront challenges, face the hurdles and overcome them appropriately. Skard posits that despite the discrepancies in cultural, socio-economic, and religious obstructions for women in their political life, there are instances when women lead peaceful opposition to resist tyrannical powers of the time (Skard, 2015, p. 156).

We argue that Nasim Wali Khan was a confident and determined lady who fought well against all odds. Nasim Wali Khan took the lead and struggled for the rights of Pukhtuns. However, she worked and endeavoured within the law in a very systematic way. Though, she was challenging the actions of the government by substituting the banned party (NAP) with the new name i.e., NDP having the same party and comrades, nonetheless, she did not rebel against the law and performed within the system. She reformed a political party through which she raised awareness among the masses by talking to them about injustices made against her family and party. She was doing sensible politics in difficult times. She led the party, arranged mass gatherings, rallies and made speeches valiantly. She resisted the atrocities of the government courageously.

Thus, those women who possess masculine strategies are competent to make their way to the top (Wagner-Wright, 2011, p. 1). Moreover, leaders having skills to use their personal experiences and convince voters of their masculine features in addition to the utilization of the traditional role of women further increase chances of success in their political careers. The dissatisfaction of the public caused by governments or former party leaders granted success to women with possession of gender- typed feminine leadership skills. Therefore, females with masculine traits succeeded as public leaders and earned power as compared to those with feminine traits only (Mansbach \& Taylor, 2012, p. 30).

After evaluating the interview data, we posit that the political life of Nasim Wali Khan was the combination of both the masculine (courage, authoritative and competitive) and feminine (caring, sensitive, empathetic, dealing interpersonal relations efficiently) features. Her 
leadership style was suitable to the circumstances. She used emotional speeches and conveyed her destitution in front of the masses to gain sympathies and support, but on the other side, we see an exacting leader in Nasim Wali Khan who held dictatorial powers in the party and took a tough stance against the government. The confidence which she demonstrated in her actions further grooms her leadership.

Nasim Wali Khan's confidence and courage can be elucidated properly from her statement in one of her interviews with Razia Bondery in The Herald in 1977. She argued: "Her presence in active politics and the revelation of her suffering before the masses is not to be called as 'mazloom'. God forbid, I am not a mazloom. Those people who can raise a voice for their rights are never mazloom. It is an insult to call them mazloom. I have never considered nor call myself a mazloom" (Bondery, 1977).

According to M. I. Malik in Weekly Lail-o-Nihar, Nasim Wali in her speech in Punjab procession of NDP on $4^{\text {th }}$ December 1975 asserted, "It is our cultural norm that we don't bow before others and are not saleable" (Malik, 1975). Likewise, M. I. Malik (1976) in Weekly Islami Jamhooria further states that in another speech, she claimed: "Those who are afraid of the situation have left the field, or either bow in front of the tyrannies or are sold but still there is the presence of those courageous people who stood against the odds..." (She provoked the public by stating), "there is no need to be worried from these conditions. Vivacious nations are the ones who confront and oppose the agony. There is no need to be scared of the darkness as every night has to be followed by the day. Such nations are favourable to Allah who faced difficulties with patience and endurance. The only requirement of the time is unity. We should move forward unitedly to get rid of the darkness" (Malik, 1976, p. 22). This speech exhibits her confidence. The morale and spirit of the public were lifted by the personal manifestation of courage by Nasim Wali Khan. They accompanied Nasim Wali in her struggle primarily because they were inspired by her determination.

Likewise, her colleague Mazari applauded her courageous attitude in his biography. He argued that she never hesitated by playing an active role in opposition. He narrated an account that once Nasim Wali helped her daughter to design and stitch the flag of the newly formed party (NDP). Despite the tough stance of the government against the opposition parties, Nasim Wali Khan was the one who lifted the party's flag on the roof of Mazari's house in Karachi on $9^{\text {th }}$ May 1976 at a meeting for the party workers. Mazari further adds that she always accompanied them in the processions and rallies besides attending the conspiracy trial against Abdul Wali Khan in Hyderabad Central jail (Mazari, 1999:401).

Sherbaz Mazari explains her determination and courage saying, Nasim Wali Khan faced house arrest several times during Z. A. Bhutto and Zia ul Haq's regimes, however, nothing could abstain her from attaining her goals. Mazari posits that she was also a leading member of the PNA campaign of the mass protest against rigging in the 1977 elections. She was detained from Karachi on $17^{\text {th }}$ March 1977 among other PNA members, and was sent to Peshawar (Mazari, 1999, p. 448). Similarly, Nasim Wali Khan among other PNA members was also detained in Sihala Rest House which was converted into a jail (Mazari, 1999, pp. 454 \& 502). Nevertheless, she was enthusiastic to continue her struggle against the autocratic regime.

Nasim Wali Khan posits that her perseverance encouraged her which was helpful in the achievement of the task. She further admired herself by stating: "I am a very determined person and ponder that I should always do whatever I can. If a person doesn't possess an ability to do 
certain work that person should avoid doing it" (Nasim Wali Kahn, personal interview, 2017). Thus, self-confident and determined leaders earn acceptance and success in the political sphere. Nasim Wali Khan's confidence and hard work paid her well during the 1977 elections when she won from the two constituencies NA-4 (Peshawar-IV) and NA-8 (Mardan-III) of erstwhile NWFP on general seats and became the member of $6^{\text {th }}$ National Assembly. However, she didn't take an oath because of the boycott of opposition parties against rigging in elections (Mittra \& Kumar, 2004, p. 56).

Wolpert posits that after the 1977 elections, the situation went from bad to worse. The PNA called it rigged elections and indicated that the popular votes were embezzled by the PPP "election thieves" (1993: 283). PNA issued a call for strikes against the rigged government. They started demanding the resignation of Z. A. Bhutto's and to rescheduled free and fair elections. Z. A. Bhutto tried to persuade PNA to call off all its demands. Wolpert states that Nasim Wali Khan issued "an ultimatum to the chairman of the ruling party PPP to accept the demands of the PNA by April $20^{\text {th }}$ or face the consequences" (Wolpert, 1993, p. 288). We argue that the leadership of Nasim Wali Khan cannot be completely attributed to her political lineage alone but can be the result of leadership potentials too that she possessed. As a political leader, she attempted to find and preserve a balance between confrontation and non-violence. Her visits to numerous parts of the country, persuading the public to join her movement, is evince of her confidence.

Wadaan Uddin Khaksar (an old political worker of ANP) in his interview with the author dedicates a Pukhtu proverb to Nasim Wali Khan. He admired Nasim Wali Khan's confidence and courage and posits 'Che do shah zalmo na pora na shwa; fakhri Afghana jenake be de gateena'. If the young could not defend you, $\mathrm{O}$ my motherland, your maidens will come forward for your defense (Wadan Udding Khaksar, personal interview, 2018). Nasim Wali Khan argues that the troubles we face in our lives familiarize us with the valuableness of the skills/resources we possess. Problems in our lives give us confidence and strength (Nasim Wali Khan, personal interview, 2016).

\section{Conclusion}

Women in the patriarchal Pukhtun society face numerous hurdles to join the political sphere culturally conceived men's sphere. However, few women political leaders successfully show their presence in the political sphere with their exceptional skills. Likewise, Nasim Wali Khan through her political apprenticeship successfully occupied the male- dominated political field and accomplished her objectives. Her dedication and motivation for seeking political office through public service further enhanced her chances of success. It is because of her skills that she proved herself as the most influential lady of ANP and a formidable opposition leader of the 1970s. Abiding by her traditions, she was cherished by her followers, who offered full support to her. They stood by her side at the time of suffering and accompanied her in her political struggle. Nasim Wali Khan skillfully gained the support of the masses and party leaders, even those who were initially her adversaries. Throughout her political career confidence, courage and good communication skills enabled her to confront challenges and successfully achieve her tasks. She gained the affectionate title of Mor Bibi from her supporters. She is remembered as the first-ever Pukhtun and Pakistani lady to win the election on general seats, a rare political achievement indeed. One can conclude from the above discussion that women political leaders can achieve greater accomplishments whenever they get opportunities. 


\section{References}

Ahmed, A. (2006). Sorrow and Joy among Muslim Women: The Pakhtuns of Northern Pakistan. Cambridge University Press.

Ahmed, S. A. (1980). Pukhtun Economy and Society: Traditional Structure and Economic Development in a Tribal Society. London, Routledge and Kegan Paul.

Ammeter, A. P., Douglas, C., Gardner, W. L., Hochwarter, W. A., \& Ferris, G. R. (2002). Toward a political theory of leadership. The Leadership Quarterly, 13(6), 751-796. https://doi.org/10.1016/S1048-9843(02)00157-1

Bass, B. M. (1999). Two Decades of Research and Development in Transformational Leadership. European Journal of Work and Organizational Psychology, 8(1), 9-32. https://doi.org/10.1080/135943299398410

Bennister, M. (2012). Prime Ministers in Power: Political Leadership in Britain and Australia. Palgrave Macmillan.

Bondrey, R. (1977, September). In interview with Nasim Wali Khan. The Herald.

Cornwall, A., \& Goetz, A. M. (2005). Democratizing democracy: Feminist perspectives. Democratisation, 12(5),

783-800. https://doi.org/10.1080/13510340500322181

Derichs, C., Thompsons, R. M. (2013). Dynasties and Female Political Leadership in Asia. LIT Verlag Fresnostr.

Driedger, M. (2013). Challenges for Women in Politics. Canadian Parliamentary Review. http://www.revparl.ca/36/3/36n3e_13_Driedger.pdf

Ferris, G. R., Treadway, D. C., Kolodinsky, R. W., Hochwarter, W. A., Kacmar, C. J., Douglas, C., \& Frink, D. D. (2005). Development and validation of the political skill inventory. Journal of Management, 31(1), 126-152. https://doi.org/10.1177\%2F0149206304271386

Fleschenberg, A. (2008). “Asian's Women Politician at the Top: Roaring Tigresses or Tame Kittens"? In Iwanaga, Women Political Participation and Representation in Asia: Obstacles and Challenges (ed). Nordic Institute of Asian Studies Press.

Grima, B. (1992). The Performance of Emotions among Paxtun Women.

Habermass, J. (1984). The Theory of Communicative Action: Reason and Rationalization of Society. Translated by McCarthy, vol 1. Boston: Beacon Press.

Hassan, A. Q. (1977, May 6). Interview with Nasim Wali in Weekly Afrasia. p. 11.

Haslam, S. A. (2004). Psychology in Organizations: The Social Identity Approach (2 ${ }^{\text {nd }}$ edition). Sage.

Ihsan, Zubida (2017, March 2). Zubida Ihsan was interviewed by the first author at Peshawar. Jalalzai, F., Krook, L.M. (2010). Beyond Hillary and Benazir: Women's Political Leadership Worldwide. International Political Science Review, 31(1), 5-23. https:/doi.org/ $10.1177 / 0192512109354470$

Jalalzai, F., Rincker, M. (2018). "Blood is Thicker than Water: Family Ties to Political Power Worldwide". Historical Social Research, 43(4), 54-72. https://doi.org/10.12759/hsr.43.2018.4.54-72

Kakakhail, S. W. A. S. (2012). Pukhtane Khaze ao da Qaom Khidmat. Gul Zaman Press.

Katz, Elihu; Blumler, G. Jay\& Gurevitch, Michael. (1974). Utilization of Mass Communication by the Individual. In: Blumler, \& Katz, The Uses of Mass Communications: Current Perspectives on Gratifications Research (eds). Sage.

Kaushik, S.N. (1984). Politics in Pakistan._With Special Reference to Rise and Fall of Bhutto. Reproduced by Panhwar (member Sindh council). 
Khaksar, Wadan Uddin (2018, July 10). Wadan Uddin Khaksar was interviewed by the first author at Peshawar.

Lave, J., Wenger, E. (1991). Situated learning: legitimate peripheral participation. Cambridge University Press. https://doi.org/10.1017/CBO9780511815355

Lindsay, L. L. (1997). Gender Role - A Sociological Perspective. Routledge.

Lussier, N. R., Achua, F. C. (2013). Who is a leader and what skill a leader needs (pp. 10-11). In: Leadership; Theory, Application and Skill Development, $5^{\text {th }}$ edition. Nelson Education.

Malik, M. I. (1975). Nasim Wali Khan speech. Weekly Lail-o-Nihar (ed), pp. 11-12 \& 16.

Malik, M. I. (1976). Nasim Wali Khan speech, Weekly Islami Jamhooria (ed), 21-22.

Mansbach, W. R., Taylor, L. K. (2012). Introduction to Global Politics. Routledge. https://doi.org/10.4324/9781315301839.

Mazari, S. K. (1999). A Journey to Disillusionment. Oxford University.

Mittra, S., Kumar, B. (2004). Encyclopaedia of Women in South Asia. Kalpaz Publications.

Neely, T.M. (2012). Nine Women World Leaders: Sexism on the Path to Power. Thesis Master of Arts. The University of Texas, 1-118.

Qalander, I. (ed). (1977). Interview with Begum Ghulam Mohammad Bilour. Weekly Afrasia.

Sarwar, R. G. (1976). Nasim Wali Khan Speech. In: Hassan (ed), Weekly Afrasia (ed). pp. 8 \& 28.

Skard, T. (2015). Women of power: Half a century of female presidents and prime minister worldwide. https://doi.org/10.1017.S0022216X16001632

Stock, D. M. (2012). Making politics personal: Leadership programs as a tool for developing political interest and efficacy in young women. University of Missouri-Saint Louis. https://irl.umsl.edu/dissertation/372

Storey, J., Hartley, J., Denis. L, J., Hart. P., Ulrich, D. (2017). The Routledge Companion to Leadership. Taylor \& Francis.

Vandal, H. S., Khan, T., Hassan, F. (2013). Social Practices: Promoting Peace and Social Cohesion through heritage education. UNESCO.

Wenger, E. (1998). Communities of practice. Cambridge University. https://doi.org/10,1017/CBO9780511803932

Wagner-Wright, S. (2012, March). Common denominators in successful female statecraft: the political legacies of Queen Elizabeth I, Indira Gandhi, and Margaret Thatcher. In Forum on Public Policy: A Journal of the Oxford Round Table. Forum on Public Policy.

Wijekoon, L. (2000). Why Do South and Southeast Asians Vote for Female Heads of State? Asian Journal of Political Science, 2, 57-72. https://digital.commons.iwu.edu/respublica/vol10/iss1/7.

Wolpert, S. (1993). Zulfi Bhutto of Pakistan: His life and times. Oxford.

Yammarino, J. F., Mumford, D. M. (2012). Leadership and organizational politics: A multilevel review and framework for pragmatic Deals. In: Ferris \& Treadway, Politics in Organizations: Theory and Research consideration (eds). Taylor \& Francis. https://doi.org/10.4324/9780203197424

Zimmerman, B. P., Kanter, M. R. (2012). Advanced Leadership and Decision-Making: An Essential Skill in Decision-Making for Leaders. Advanced Leadership Initiative at Harvard University. 


\section{Appendices}

Appendix-1: List if Interviewees

\begin{tabular}{|l|l|l|l|}
\hline Interviewee & Details & Place & Dates \\
\hline $\begin{array}{l}\text { Nasim Wali } \\
\text { Khan }\end{array}$ & Ex-vice president of ANP & $\begin{array}{l}\text { Wali Bagh, } \\
\text { Charsadda. }\end{array}$ & $\begin{array}{l}10^{\text {th }} \text { March } 2016 \\
19^{\text {th }} \text { May } 2017\end{array}$ \\
\hline Farid Tofan & Politician; Former Gen. Secretary of ANP (W) & Peshawar & $2^{\text {nd }}$ Nov 2016 \\
\hline Fayaz Khan & $\begin{array}{l}\text { Lawyer by profession and relative of Nasim } \\
\text { Wali Khan }\end{array}$ & Mardan & $2^{\text {nd }}$ June 2017 \\
\hline Hameed Khan & $\begin{array}{l}\text { Lawyer and ex-district (Mardan) president of } \\
\text { ANP }\end{array}$ & Mardan & $2^{\text {nd }}$ June 2017 \\
\hline $\begin{array}{l}\text { Khadim } \\
\text { Hussain }\end{array}$ & $\begin{array}{l}\text { Pukhtun intellectual; Director at Bacha Khan } \\
\text { Trust and Educational Foundation }\end{array}$ & Peshawar & $10^{\text {th }}$ May 2017 \\
\hline $\begin{array}{l}\text { Munawar } \\
\text { Sultana }\end{array}$ & $\begin{array}{l}\text { Politician; Vice-president of ANP; Ex-MPA KP } \\
\text { Assembly (2008-2013) }\end{array}$ & Peshawar & $27^{\text {th }}$ April, 2017 \\
\hline Naeema Bibi & Close family member of Abdul Wali Khan & Peshawar & $\begin{array}{l}6^{\text {th }} \text { September } \\
2016\end{array}$ \\
\hline $\begin{array}{l}\text { Rahimullah } \\
\text { Yousafzai }\end{array}$ & Senior Journalist; security and political analyst & Peshawar & $\begin{array}{l}10^{\text {th }} \text { May } 2016 \\
6^{\text {th }} \text { July } 2017\end{array}$ \\
\hline $\begin{array}{l}\text { Shagufta } \\
\text { Malik }\end{array}$ & $\begin{array}{l}\text { Politician from ANP; MPA (KP Assembly } \\
\text { 2008-2013; 2018-till date) }\end{array}$ & Peshawar & $10^{\text {th } \text { May } 2017}$ \\
\hline $\begin{array}{l}\text { Wadan Uddin } \\
\text { Khaksar }\end{array}$ & Ex-Gen. secretary of ANP & Peshawar & $10^{\text {th }}$ July 2018 \\
\hline Zubaida Ihsan & $\begin{array}{l}\text { ANP MPA KP Assembly (2008-13); Mother-in- } \\
\text { Law, Federal Minister of State, Parliamentary }\end{array}$ & Peshawar & $2^{\text {nd }}$ March 2017 \\
\hline
\end{tabular}

Appendix-2: Interview Schedule

1. If you could kindly introduce yourself.

2. In what capacity do you know Nasim Wali Khan? how well and for how long do you know her.

3. What factors (other than family background and political exigency) were instrumental in acquiring political leadership by Begum Nasim Wali Khan?

4. What specific political skills enabled her to attain and retain political leadership position?

5. How did she use her political skills to overcome the hurdles she faced in her way to progress?

6. What was the reaction of the Pukhtun society towards her leadership?

7. How did she communicate with followers and colleagues in strict codes of Pukhtunwali (Parda)?

8. Were speeches of Nasim Wali Khan effective enough to attract the general public? How so?

9. How was she able to gain the support of her society?

10. Was there any resistance to her leadership within her party and outside? If there was any opposition how she dealt with it.

\section{Notes:}

\footnotetext{
${ }^{1}$ She was a political activist, close associate of Begum Nasim Wali Khan and wife of a renowned political leader of ANP Ghulam Ahmad Bilour (former MNA, served as federal minister for railway twice and federal minister for local government and rural development once).

${ }^{2}$ He was sardar of the Mazari tribe entered into the political sphere in elections of 1965 against Ayub Khan. In 1970, he became an elected National Assembly member as an independent candidate. He led the independent group in National Assembly and was a signatory to 1973 Constitution. Later, he became the President (1975-77) of newly formed National Democratic Party. He was a prominent leader of Pakistan National Alliance (1977-81) and Movement for the restoration of Democracy (1981-88).
} 